\title{
HPV and the Development of Colorectal Cancer
}

\author{
Mohamad Nidal Khabaz ${ }^{1}$ \\ ${ }^{1}$ Department of Pathology, Rabigh Faculty of Medicine, King Abdulaziz University, Jeddah 21589, Saudi Arabia. \\ Correspondence: Mohamad Nidal Khabaz, Department of Pathology, Rabigh Faculty of Medicine, King \\ Abdulaziz University, Jeddah 21589, Saudi Arabia. Tel: 966-563998879. E-mail: mnkhabaz@kau.edu.sa
}

Received: June 29, 2016 Accepted: August 8, 2016 Online Published: August 25, 2016

doi:10.5539/gjhs.v9n4p251 URL: http://dx.doi.org/10.5539/gjhs.v9n4p251

\begin{abstract}
Over the past two decades, many studies reported that around (20\%) of the worldwide malignant tumors problem can be related to viral infections. Some publications recently have described a relationship between malignant colorectal tumors and human papilloma virus (HPV), but these findings are still debatable. The purpose of this report is to evaluate the existence of the genetic sequences and the proteins of HPV in the transformed cells of colorectal cancer in Saudi Arabia. Extracted DNA from eighty three archival colorectal tumor samples were examined for HPV DNA types 16 and 18 and their protein products using polymerase chain reaction (PCR) technique in addition to immunohistochemical staining. All colorectal cancer and control cases were found negative for both 16 and $18 \mathrm{HPV}$ types by using PCR. Moreover, immunostaining did not detect any nuclear expression of HPV proteins in all examined cases. Our outcomes supports the statement that HPV is not engaged in the initiation and progression of colorectal carcinomas especially in the Western province of Saudi Arabia.
\end{abstract}

Keywords: colorectal cancer, human papilloma virus, Saudi Arabia, immunohistochemistry

\section{Introduction}

The incidence of the entire infection-attributable neoplasms in 2002 was almost two million cases, or $18 \%$ of the worldwide tumor burden (Parkin, 2006). Numerous kinds of tumors can be initiated by the revelation to various infective agents, bacteria or viruses, for instance cervical cancer linked to human papilloma virus (HPV) infection (Zur Hausen, 2002), hepatocellular carcinoma to hepatitis B virus (Blumberg and London, 1985), adult T-cell leukemia/lymphoma (ATL) to HTVL-1 (Matsuoka and Jeang, 2007), Burkett lymphomas to Epstein-Barr virus (Kuppers, 2009), gastric carcinoma to Helicobacter pylori (Burnett-Hartman, Newcomb, \& Potter, 2008), and lately XMRV, a member of Retroviridae family, has been allied with prostatic carcinoma (Urisman et al., 2006).

HPV is a tiny virus with dual DNA strands that belong to papilloma Viridae family (Shukla et al., 2009). Papilloma viruses are blamed for widespread infections and papillomatous growths in humans and animals. They appear to intermingle synergistically with physical and chemical cancer-causing agents, and thus appear to act as tumor promoters (Cheng, Sheu, Meng, Lee \& Lin, 1995). Human papilloma viruses have been found in many epithelial tumors, including larynx, pharynx, oral cavity, penis, anus, and cervical cancers (D'Souza, et al., 2007; Bodaghi et al., 2005; Steenbergen et al., 2005; Munoz, 2000). Up to date, in excess of 100 distinct forms of HPV have been recognized, however, types such as $16,18,31,33,35,39,45,51$, and few others are grouped as high risk oncogenic infectious agents, and counted as carcinogens (Wiley and Masongsong, 2006; Munoz, Bosch \& de Sanjose, 2003). The oncogenicity of these viruses is related to their E6 and E7 viral protein expressions, which allow and facilitate the transformation process into malignant cells (Burnett-Hartman et al., 2008). E6 inactivates the protein product of $\mathrm{p} 53$ and stimulates telomerase, thereby cells will eternalize. Accordingly, HPV associated neoplasms often have p53 mutations (Bodaghi et al., 2005; Tommasino et al., 2003). While, E7 has been identified to attach and disable retinoblastoma protein (pRB), and ultimately guides to $\mathrm{p} 16$ INK4A upregulation (Yavuzer et al., 2011; Bodaghi et al., 2005). Furthermore, HPV oncoproteins (E6, E7) activate the ras family including K-ras (Buyru, Tezol \& Dalay, 2006). A relationship between the development of malignant colorectal tumors and human papilloma virus infection was described (Yavuzer et al., 2011; Burnett-Hartman et al., 2008; Damin et al., 2007). However, HPV aetiology of colorectal cancer is still an intriguing subject (Gazzaz, Mosli, Jawa, \& Sibiany 2016; Aghakhani et al., 2014; Taherian, Tafvizi, Fard \& Abdirad, 2014; Gornick et al., 2010).

In Saudi Arabia, colorectal tumors are the main cause of morbidity and tumor death, of which 1230 cases were reported in 2012, accounting for $11.1 \%$ of all newly reported tumors. Colorectal cancer placed first amongst Saudi males and third amongst Saudi females. It influenced 675 (54.9\%) men and 555 (45.1\%) women with a man to 
woman ratio of 122:100. The median age was 59 years among men and 58 years among women. The most common morphological type was adenocarcinoma (NOS) and far less frequent were mucinous adenocarcinoma, signet ring cell carcinoma, and other types. Young patients, who are less than 50 years, were almost $20 \%$ of all cases of colorectal cancer (Al-Zahrani et al., 2015). The goal of this research is to investigate the incidence of HPV DNA and its proteins in colorectal carcinoma.

\section{Material and Methods}

Eighty three cases of colorectal cancer and 35 control cases, which include adenomas, polyps, nearby normal mucosa and remote surgical boundaries of colorectal tissues, were recruited in this research. Paraffin blocks of all recruited cases and clinicopathological parameters (age, gender, histotype, grade and stage) have been collected from the pathology department at King Abdulaziz University. Colorectal cancer patients have experienced neoplasm resections and dissection of regional lymph nodes at King Abdulaziz University Teaching Hospital.

Cases of colorectal cancer with family history or who received radiotherapy and/or chemotherapeutic agents were excluded from the present study. Thirty five control cases included 15 women and 20 men. The average age was 57 years (ranged from 28 to 87 years). All samples of control cases were obtained from entities with noncancerous lesions (polyps and adenoma), in addition to adjacent normal tissue and remote surgical margins. All paraffin embedded tissue blocks of recruited cases were serially sectioned and utilized in the current research project. The present study was approved by the King Abdulaziz University Biomedical Ethical Committee.

\subsection{Immunohistochemistry (IHC) Staining Protocol}

Four micron thickness sections from all cases were utilized in immunohistochemistry staining protocol as described by Khabaz (2013). Mouse monoclonal antibody for human papilloma virus (Thermo Scientific, UK) was used. Positive and negative controls were included. Two slides containing cervical cancer specimens, which were known to hold types 16 and 18 HPV viruses, ran concurrently with all cases. The primary antibody has been replaced with diluted normal serum as a negative control. All cases, which have more than one percent of the tumor cells showing nuclear brown immunostaining, were considered positive.

\subsection{DNA Isolation Protocol}

Adequate samples from paraffin tissue blocks of all recruited cases were utilized for genomic DNA isolation using commercial kit from Qiagen in Germany (QIA amp DNA FFPE kit), according to the manufacturer's guidelines. Extracted DNA was saved at $-40^{\circ} \mathrm{C}$. Nanodrop- 2000 (Thermo Scientific) was used for the analysis of DNA purity and concentration.

\subsection{Primers Selection}

After comprehensive literature search the primers, which were used by Yavuzer et al, 2011 and Damin et al, 2007 (Yavuzer et al., 2011; Damin et al., 2007), were chosen. The primers of GAPDH gene were utilized to inspect the presence and quality of DNA (Table 1).

Table 1. Selection of PCR primers

\begin{tabular}{ll}
\hline Virus & Sequence \\
\hline \multirow{2}{*}{ HPV-16 } & Forward: CACAGTTATGCACAGAGCTGC \\
& Reverse: TATATTCATGCAATGTAGGTGTA \\
\hline \multirow{2}{*}{ HPV-18 } & Forward: CACTTCACTGCAAGACATAGA \\
& Reverse: GTTGTGAAATCGTCGTTTTTCA \\
\hline \multirow{2}{*}{ GAPDH } & Forward: GGCCTCCAAGGAGTAAGACC \\
& Reverse: CCCCTCTTCAAGGGGTCTAC \\
\hline
\end{tabular}

\subsection{Polymerase Chain Reaction Amplification}

Human genome was confirmed to be present by amplifying GAPDH gene. Revealing the HPV 16 and 18 DNA in colorectal neoplasms was completed employing the cyber green PCR kit (Qiagen) according to the producer's guidelines. $200 \mathrm{ng}$ DNA was included in $25 \mu$ reaction. HPV oligonucleotide primers (Eurofins Genomics, UK) were used (Table 1). A thermocycler 480 (Applied Biosystems, CA, USA ) was utilized for DNA amplification reaction, starting with first denaturation step for $15 \mathrm{~min}$ at $94{ }^{\circ} \mathrm{C}$, after that 35 denaturation cycles at $94{ }^{\circ} \mathrm{C}$ timed $1 \mathrm{~min}$ each were completed, followed by annealing step for $1 \mathrm{~min}$ at $57^{\circ} \mathrm{C}$, and extension of $60 \mathrm{sec}$ at $74{ }^{\circ} \mathrm{C}$. At the end, the last extension at $72{ }^{\circ} \mathrm{C}$ for ten min was completed. Controls (positive and negative) were incorporated in 
each test. 1.5\% agarose gel electrophoresis and UV-transilluminator (SYNGENE, UK) were used to visualize the PCR product.

\subsection{Statistical Analyses}

IBM-SPSS version 21 was utilized for statistical studies. Association between examined variables was determined by using Chi-Square test.

\section{Results}

All the 83 recruited cases of colorectal cancer were reviewed. The age of the colorectal cancer subjects ranged from 22 to 94 years with average $57.8 \pm 12.8$ years. Colorectal cancer cases of the present study showed a small preponderance of women $45(54.2 \%)$.

Moderately differentiated tumors were the most common type accounting for $48.2 \%$ of the cases. This type was more prevalent among male population (52.6\%) than female population (44.4\%). Less frequently were well differentiated tumors $(38.55 \%)$ while the least in occurrence were tumors of poor differentiation which recorded higher incidence in female population (Table 2). In frequent order, A, B1, B2, C2, and D were the grades, using modified Duke's grading system, of colorectal cancer cases in the present study and they represented $1.2 \%, 2.4 \%$, $55.5 \%, 34.9 \%$, and $6 \%$ respectively. Grade B2 tumors were more common among females accounting for $66.7 \%$ and $42.1 \%$ among males. Grade C2 tumors were more frequent among male population accounting for $47.4 \%$, which is almost twice the incidence in female population (Table 2).

Table 2. Clinicopathological characteristics of patients with colorectal cancer

\begin{tabular}{|c|c|c|c|c|c|c|c|}
\hline \multirow{2}{*}{ Characteristics } & & \multicolumn{2}{|c|}{ All patients } & \multicolumn{2}{|c|}{ Female } & \multicolumn{2}{|c|}{ Male } \\
\hline & & No & $\%$ & No & $\%$ & No & $\%$ \\
\hline Total cases & & 83 & 100 & 45 & 54.2 & 38 & 45.8 \\
\hline \multirow{5}{*}{ Age } & $<40$ & 6 & 7.23 & 5 & 11.11 & 1 & 2.6 \\
\hline & $40-49$ & 12 & 14.45 & 6 & 13.3 & 6 & 15.8 \\
\hline & $50-59$ & 28 & 33.74 & 13 & 28.8 & 15 & 39.5 \\
\hline & $60-69$ & 23 & 27.72 & 12 & 26.6 & 11 & 28.9 \\
\hline & $\geq 70$ & 14 & 15.66 & 9 & 20 & 5 & 13.2 \\
\hline Average age & $57.8(22-94)$ & & & & & & \\
\hline \multirow{7}{*}{ Tumor location } & Ascending colon & 18 & 21.69 & 11 & 24.4 & 7 & 18.4 \\
\hline & Transverse colon & 4 & 4.82 & 3 & $6 . .6$ & 1 & 2.6 \\
\hline & Descending colon & 13 & 15.66 & 7 & 15.5 & 6 & 15.78 \\
\hline & Rectum & 15 & 18.08 & 6 & 13.3 & 9 & 23.68 \\
\hline & Recto-sigmoid & 12 & 14.45 & 7 & 15.5 & 5 & 13.15 \\
\hline & Sigmoid & 17 & 20.48 & 9 & 20 & 8 & 21.05 \\
\hline & Cecum & 4 & 4.82 & 2 & 4.4 & 2 & 5.26 \\
\hline Average size of tumor & $5 \mathrm{~cm}(0.6-12)$ & & & & & & \\
\hline \multirow{2}{*}{ Lymph node involvement } & Yes & 32 & 38.6 & 15 & 33.3 & 17 & 44.7 \\
\hline & No & 51 & 61.4 & 30 & 66.7 & 21 & 55.3 \\
\hline \multirow{3}{*}{ Tumor differentiation } & Well with/or without mucinous & 32 & 38.55 & 17 & 37.8 & 15 & 39.4 \\
\hline & Moderate with/or without mucinous & 40 & 48.2 & 20 & 44.4 & 20 & 52.6 \\
\hline & Poor with/or without mucinous or signet ring cells & 11 & 13.25 & 8 & 17.8 & 3 & 7.9 \\
\hline \multirow{5}{*}{ Duke's grading system } & A & 1 & 1.2 & 0 & 0 & 1 & 2.6 \\
\hline & B1 & 2 & 2.4 & 0 & 0 & 2 & 5.3 \\
\hline & B2 & 46 & 55.5 & 30 & 66.7 & 16 & 42.1 \\
\hline & $\mathrm{C} 2$ & 29 & 34.9 & 11 & 24.4 & 18 & 47.4 \\
\hline & $\mathrm{D}$ & 5 & 6 & 4 & 8.9 & 1 & 2.6 \\
\hline
\end{tabular}


In the present study, colorectal cancers were distributed approximately similarly in both males and females as regards of anatomic location, and the prevalence of these tumors were $21.69 \%, 20.48 \%, 18.08 \%, 15.66 \%, 14.45 \%$ and $4.82 \%$ in the following anatomic sites; ascending, sigmoid, rectum, descending, recto-sigmoid, and cecum respectively. Lymph node involvement has been reported in $38.6 \%$ of the neoplasms. The size of colorectal tumors ranged from 0.6 to $12 \mathrm{~cm}$ with median size of $5.0 \pm 2.6 \mathrm{~cm}$ (Table 2). The amplified DNAs of all tumor and control cases contain neither type 16 nor type 18 of HPV (Table 3 ). Moreover, immunohistochemical staining did not detect the nuclear expression of HPV proteins in both control and cancer cases (Table 3).

Table 3. Results of HPV detection protocols

\begin{tabular}{lllllll}
\hline & \multicolumn{2}{l}{ Colorectal cancer cases (83) } & & \multicolumn{2}{l}{ Non-cancerous cases (35) } & Positive control \\
\cline { 2 - 3 } & Positive & Negative & & Positive & Negative & \\
\hline $\begin{array}{l}\text { PCR } \\
\text { amplification }\end{array}$ & 0 & 83 & & 0 & 35 & $\begin{array}{l}\text { HPV Mix included in commercial } \\
\text { kit }\end{array}$ \\
\hline $\begin{array}{l}\text { Immunohistoche } \\
\text { mistry detection }\end{array}$ & 0 & 83 & & 0 & 35 & $\begin{array}{l}\text { Cervical cancer, which were known } \\
\text { to hold types 16 and 18 HPV viruses }\end{array}$ \\
\hline
\end{tabular}

\section{Discussion}

The relationship between viral infection and neoplasm initiation and progression has been recognized few decades ago. The World Health Organization classified HPV as group I carcinogen, which can certainly initiate tumors in humans. Since then few reports have suggested that HPV may be engaged in the tumorigenesis of colorectal cancer. They only detected the virus in anal carcinomas (Koulos, Symmans, Chumas, \& Nuovo, 1991; Boguszakova et al., 1988). Later in 1995, Cheng et al. (1995) were the first to report HPV involvement in colorectal carcinoma. However, HPV has continued to be a debatable subject as a carcinogenic agent of colorectal cancer (Gazzaz et al., 2016; Aghakhani et al., 2014; Taherian et al., 2014; Burnett-Hartman et al., 2011; Gornick et al., 2010; Damin et al., 2007; Perez, Abba, Laguens, \& Golijow, 2005; Shah, Daniel, Simons, \& Vogelstein, 1992; Shroyer et al., 1992). Furthermore, the exact role of HPV in colorectal pathogenesis is somehow not clear. Therefore, the current research aimed to examine the presence of HPV in colorectal carcinoma in Saudi population.

Although a small number of studies have documented the presence of HPV in colorectal tumor cells (Damin et al., 2007; Perez et al., 2005; Cheng et al., 1995), PCR and immunohistochemistry staining did not identify the DNA of HPV and its protein in the tested tumor tissues and control group in the present study. Our outcomes are consistent with other studies, which could not reveal the DNA of HPV in colorectal tumors and controls (Gazzaz et al., 2016; Aghakhani et al., 2014; Taherian et al., 2014; Yavuzer et al., 2011; Gornick et al., 2010; Urisman et al., 2006; Perez et al., 2005; Boguszakova et al., 1988; Shah et al., 1992). In one of these studies conducted by Aghakhani et al. (2014), the team examined the incidence of HPV genome in 70 samples of colorectal neoplasms, and 30 patients with adenoma and 30 tumor adjacent tissues (as control). All tested carcinomas and adenomas as well as tumor adjacent tissues were negative for all types of HPV in two PCR assays. Other research, conducted by Taherian et al. (2014), could not identify HPV DNA in the recruited cases. These discrepancies can be clarified by the differences among sample sizes of previous studies, technique sensitivity, population geographic diversity, strains of HPV and its incidence. In addition, false-positive results because of contamination may count in this type of studies because molecular techniques are extremely susceptible and viral genome can disseminate simply at any phase of the test, monitoring and limiting viral contamination is critical to guarantee dependable outcomes. Furthermore, the type of studied tissue is the base of all investigations, for example most experiments utilized paraffin tissue blocks which should be cut independently employing sterilized blades, i.e., avoiding contagion during microtome cutting necessitates different sterilized knifes and systematic cleaning of the apparatus. Failure to adapt these procedures may disseminate infection between tissue samples and cause false-positive results (Yavuzer et al., 2011; Burnett-Hartman et al., 2011). Another noteworthy factor is HPV incidence in the studied population. Alsbeih (2014) reported low prevalence of HPV in Saudi Arabia in 2014. In addition, there are several high risk HPV types, of which only few types have been investigated, keeping in mind that HPV infection alone is not adequate to initiate tumor. Furthermore, cellular changes are essential for oncogenesis, and an increase in the genetic alterations seems to appear later on (Steenbergen et al., 2005). Additionally, patient age should not be disregarded. The median age in the present study is 57.8 years, thus we assessed essentially a low risk population. In conclusion, even though we could not obtain any evidence for viral involvement in our colorectal adenoma/carcinoma series, however, evidence beyond a rational suspicion that HPV plays a part in colorectal cancer initiation and progression 
requires considerable further proofs and additional investigation.

\section{Acknowledgments}

This project was funded by the National Plan for Science, Technology and Innovation (MAARIFAH) - King Abdulaziz City for Science and Technology - the Kingdom of Saudi Arabia - award number (11- MED2034-03). The authors also, acknowledge with thanks Science and Technology Unit, King Abdulaziz University for technical support.

\section{Competing Interests Statement}

The authors declare that there is no conflict of interests regarding the publication of this paper.

\section{References}

Aghakhani, A., Hamkar, R., Ramezani, A., Bidari-Zerehpoosh, F., Sabeti, S., Ghavami, N., ... Eslamifar, A. (2014). Lack of human papillomavirus DNA in colon adenocarcinoma and adenoma. $J$ Cancer Res Ther, 10, 531-4. Retrieved from http://www.cancerjournal.net/text.asp?2014/10/3/531/137674.

Alsbeih, G. (2014). HPV Infection in Cervical and Other Cancers in Saudi Arabia: Implication for Prevention and Vaccination. Front Oncol, 4, 65. http://dx.doi.org/10.3389/fonc.2014.00065

Al-Zahrani, W. A., Al-Shahrani, Z. S., Al-Madouj, A. N., Hayder, M. S., Al-Shridah, M. M., \& Al-Shumrani, T. H. (2015). Cancer Incidence Report Saudi Arabia 2012, Saudi Cancer Registry. Retrieved from http://www.chs.gov.sa/Ar/HealthRecords/CancerRegistry/CancerRegistryReports/ 202012\%تقرير 20\%معدل0\%الإصابة\%20\%بمرض\%20\%السرطان/Adf.

Blumberg, B. S., \& London, W. T. (1985). Hepatitis B virus and the prevention of primary cancer of the liver. $J$ Natl Cancer Inst, 74, 267-273. http://dx.doi.org/10.1142/9789812813688_0039

Bodaghi, S., Yamanegi, K., Xiao, S., Da Costa, M., Palefsky, J. M., \& Zheng, Z. M. (2005). Colorectal Papillomavirus Infection in Patients with Colorectal Cancer. Clin Cancer Res, 11, 2862-7. http://dx.doi.org/10.1158/1078-0432.CCR-04-1680

Boguszakova, L., Hirsch, I., Brichacek, B., Faltyn, J., Fric, P., Dvorakova, H., \& Vonka, V. (1988). Absence of cytomegalovirus, Epstein-Barr virus, and papillomavirus DNA from adenoma and adenocarcinoma of the colon. Acta Virol, 32, 303-8.

Burnett-Hartman, A. N., Newcomb, P. A., Mandelson, M. T., Galloway, D. A., Madeleine, M. M., Wurscher, M. A., ... Schwartz, S. M. (2011). No evidence for human papillomavirus in the etiology of colorectal polyps. Cancer Epidemiol Biomarkers Prev, 20, 2288-97. http://dx.doi.org/10.1158/1055-9965.EPI-11-0450

Burnett-Hartman, A. N., Newcomb, P. A., \& Potter, J. D. (2008). Infectious agents and colorectal cancer: a review of Helicobacter pylori, Streptococcus bovis, JC virus, and human papillomavirus. Cancer Epidemiol Biomarkers Prev, 17, 2970-2979. http://dx.doi.org/10.1158/1055-9965.EPI-08-0571

Buyru, N., Tezol, A., \& Dalay, N. (2006). Coexistance of K-ras mutations HPV infection in colon cancer. BMC cancer, 6, 115. http://dx.doi.org/10.1186/1471-2407-6-115

Cheng, J. Y., Sheu, L. F., Meng, C. L., Lee, W. H., \& Lin, J. C. (1995). Detection of human papillomavirus DNA in colorectal carcinomas by polymerase chain reaction. Gut, 37, 87-90. http://dx.doi.org/10.1136/gut.37.1.87

Damin, D. C., Caetano, M. B., Rosito, M. A., Schwartsmann, G., Damin, A. S., Frazzon, A. P., ... Alexandre, C. O. (2007). Evidence for an association of human papillomavirus infection and colorectal cancer. Eur J Surg Oncol, 33, 569-74. http://dx.doi.org/10.1016/j.ejso.2007.01.014

D'Souza, G., Kreimer, A. R., Viscidi, R., Pawlita, M., Fakhry, C., Koch, W. M., ... Gillison, M. L. (2007). Case-control study of human papillomavirus and oropharyngeal cancer. $N$ Engl J Med, 356, 1944-56. http://dx.doi.org/10.1056/nejmoa065497

Gazzaz, F., Mosli, M. H., Jawa, H., \& Sibiany, A. (2016). Detection of human papillomavirus infection by molecular tests and its relation to colonic polyps and colorectal cancer. Saudi Med J, 37, 256-61. http://dx.doi.org/10.15537/smj.2016.3.13514

Gornick, M. C., Castellsague, X., Sanchez, G., Giordano, T. J., Vinco, M., Greenson, J. K., ... Moreno, V. (2010). Human papillomavirus is not associated with colorectal cancer in a large international study. Cancer Causes Control, 21, 737-43. http://dx.doi.org/10.1007/s10552-010-9502-0

Khabaz, M. N. (2013). Association of Epstein Barr virus infection and breast carcinoma. Arch Med Sci, 9, 745-751. 
http://dx.doi.org/10.5114/aoms.2013.37274

Koulos, J., Symmans, F., Chumas, J., \& Nuovo, G. (1991). Human papillomavirus detection in adenocarcinoma of the anus. Mod Pathol, 4, 58-61.

Kuppers, R. (2009). The biology of Hodgkin's lymphoma. Nat Rev Cancer, 9, 15-27. http://dx.doi.org/10.1038/nrc2542.

Matsuoka, M., \& Jeang, K. T. (2007). Human T-cell leukaemia virus type 1 (HTLV-1) infectivity and cellular transformation. Nat Rev Cancer, 7, 270-280. http://dx.doi.org/10.1038/nrc2111

Munoz, N. (2000). Human papillomavirus and cancer: the epidemiological evidence. J Clin Virol, 19, 1-5. http://dx.doi.org/10.1016/s1386-6532(00)00125-6

Munoz, N., Bosch, X. F., de Sanjose, S., Herrero, R., Castellsagué, X., Shah, K. V., ... Meijer, C. J. (2003). Epidemiologic Classification of Human Papillomavirus Types Associated with Cervical Cancer. $N$ Engl $J$ Med, 348, 518-27. http://dx.doi.org/10.1056/nejmoa021641

Parkin, D. M. (2006). The global health burden of infection-associated cancers in the year 2002. Int J Cancer, 118, 3030-3044. http://dx.doi.org/10.1002/ijc.21731

Perez, L. O., Abba, M. C., Laguens, R. M., \& Golijow, C. D. (2005). Analysis of adenocarcinoma of the colon and rectum: detection of human papillomavirus (HPV) DNA by polymerase chain reaction. Colorectal Dis, 7 , 492-5. http://dx.doi.org/10.1111/j.1463-1318.2005.00774.x

Shah, K. V., Daniel, R. W., Simons, J. W., \& Vogelstein, B. (1992). Investigation of colon cancers for human papillomavirus genomic sequences by polymerase chain reaction. $J$ Surg Oncol, 51, 5-7. http://dx.doi.org/10.1002/jso.2930510104

Shroyer, K. R., Kim, J. G., Manos, M. M., Greer, C. E., Pearlman, N. W., \& Franklin, W. A. (1992). Papillomavirus found in anorectal squamous carcinoma, not in colon adenocarcinoma. Arch Surg, 127, 741-4. http://dx.doi.org/10.1001/archsurg.1992.01420060121018

Shukla, S., Bharti, A. C., Mahata, S., Hussain, S., Kumar, R., Hedau, S., \& Das, B. C. (2009). Infection of human papillomaviruses in cancers of different human organ sites. Indian J Med Res, 130, 222-33.

Steenbergen, R. D., de Wilde, J., Wilting, S. M., Brink, A. A., Snijders, P. J., \& Meijer, C. J. (2005). HPV-mediated transformation of the anogenital tract. J Clin Virol, 32, 25-33. http://dx.doi.org/10.1016/j.jcv.2004.11.019

Taherian, H., Tafvizi, F., Fard, Z. T., \& Abdirad, A. (2014). Lack of association between human papillomavirus infection and colorectal cancer. Prz Gastroenterol, 9, 280-4. http://dx.doi.org/10.5114/pg.2014.46163

Tommasino, M., Accardi, R., Caldeira, S., Dong, W., Malanchi, I., Smet, A., \& Zehbe, I. (2003). The role of TP53 in Cervical carcinogenesis. Hum Mutat, 21, 307-12. http://dx.doi.org/10.1002/humu.10178

Urisman, A., Molinaro, R. J., Fischer, N., Plummer, S. J., Casey, G., Klein, E. A., ... DeRisi, J. L. (2006). Identification of a novel Gammaretrovirus in prostate tumors of patients homozygous for R462Q RNASEL variant. PLoS. Pathog, 2, e25. http://dx.doi.org/10.1371/journal.ppat.0020025

Wiley, D., \& Masongsong, E. (2006). Human papillomavirus: the burden of infection. Obstet Gynecol Surv, 61, S3-S14. http://dx.doi.org/10.1097/01.ogx.0000221010.82943.8c

Yavuzer, D., Karadayi, N., Salepci, T., Baloglu, H., Dabak, R., \& Bayramicli, O. U. (2011). Investigation of human papillomavirus DNA in colorectal carcinomas and adenomas. Med Oncol, 28, 127-32. http://dx.doi.org/10.1007/s12032-010-9416-4

Zur Hausen, H. (2002). Papillomaviruses and cancer: From basic studies to clinical application. Nature Rev Cancer, 2, 342-350. http://dx.doi.org/10.1038/nrc798

\section{Copyrights}

Copyright for this article is retained by the author(s), with first publication rights granted to the journal.

This is an open-access article distributed under the terms and conditions of the Creative Commons Attribution license (http://creativecommons.org/licenses/by/4.0/). 